\title{
Water footprint in the Mediterranean food chain: Implications of food consumption patterns and food wastage
}

\author{
Roberto Capone $^{1,}$, , Philipp Debs ${ }^{1}$, Hamid EI Bilali ${ }^{1}$, Gianluigi Cardone ${ }^{2}$, Nicola Lamaddalena ${ }^{3}$ \\ ${ }^{1}$ Department of Sustainable Agriculture, Food and Rural Development, Mediterranean Agronomic Institute of Bari (IAMB), International \\ Centre for Advanced Mediterranean Agronomic Studies (CIHEAM), via Ceglie 9, 70010 Valenzano, Bari, Italy \\ ${ }^{2}$ Department of Mediterranean Organic Agriculture, Mediterranean Agronomic Institute of Bari (IAMB), International Centre for \\ Advanced Mediterranean Agronomic Studies (CIHEAM), via Ceglie 9, 70010 Valenzano, Bari, Italy \\ ${ }^{3}$ Department of Land and Water Resources Management, Mediterranean Agronomic Institute of Bari (IAMB), International Centre for \\ Advanced Mediterranean Agronomic Studies (CIHEAM), via Ceglie 9, 70010 Valenzano, Bari, Italy
}

\section{Email address:}

capone@iamb.it (R. Capone)

\section{To cite this article:}

Roberto Capone, Philipp Debs, Hamid El Bilali, Gianluigi Cardone, Nicola Lamaddalena. Water Footprint in the Mediterranean Food Chain: Implications of Food Consumption Patterns and Food Wastage. International Journal of Nutrition and Food Sciences.

Vol. 3, No. 2, 2014, pp. 26-36. doi: 10.11648/j.ijnfs.20140302.13

\begin{abstract}
Consumed food type, composition and quantity affects water resources demand (cf. water footprint). Since blue water resources availability is limited in the Mediterranean area diets shifting and food losses and waste reduction are key strategies. The paper aims at analyzing the water footprint of food consumption and implications of food waste in terms of water demand. The paper is based on secondary data mainly from the FAO Food Balance Sheets and the Water Footprint Network. Approximately $91 \%$ of the water footprint (WF) in the Mediterranean is due to the consumption of agricultural products. Dietary energy ranges between 2,130 (Palestine) and 3,666 kcal/day/person (Turkey). The share of vegetal-based energy in the diet ranges from $66.5 \%$ in France to $88.9 \%$ in Palestine. Total WF of food supply in Italy (1848.3) is higher than in Finland (1116.7) but lower than in the USA $\left(2198.7 \mathrm{~m}^{3} /\right.$ capita/year). The highest water footprint is the green one, followed by the grey then the blue one. Meat and dairy products represent about a half of the WF of food supply. The contribution of cereals is significant in Southern and Eastern Mediterranean countries. The high Mediterranean consumptive water use is exacerbated by food losses and waste. In Egypt, losses in the rice supply chain are about $25 \%$. Food loss and wastage account for more than one quarter of the total consumptive freshwater use. A $50 \%$ decrease in food losses and waste at the global level would save $1,350 \mathrm{~km}^{3}$ a year. Adoption of more sustainable food consumption patterns and production systems and the reduction of food losses and waste can help reducing pressure on the scarce water resources in the Mediterranean. Food waste reduction interventions will have significant impact on freshwater resource availability as other water use efficiency measures in agriculture and food production.
\end{abstract}

Keywords: Water Footprint, Food Consumption Patterns, Mediterranean Region

\section{Introduction}

The Food and Agriculture Organization (FAO) estimated that world food production must double by 2050 . One of the greatest constraints on current and future food production is the availability of freshwater $[1,2]$. In many parts of the world, freshwater is already a scarce and overexploited natural resource, raising concerns about global food security and damage to freshwater ecosystems. In order to address the unsustainable use of global freshwater resources and meet the food production requirements of a growing world population, food chains must become much more efficient in terms of consumptive water use [3].

Agriculture already currently consumes $70 \%$ of total global 'blue water' withdrawals from rivers and aquifers available to humankind. Demand for water for agriculture could rise by over $30 \%$ by 2030 . In some arid regions of 
the world, several major non-renewable fossil aquifers are increasingly being depleted and cannot be replenished, for example in Egypt and Libya [4].

The Mediterranean receives on average only $3 \%$ of global water resources. In some countries, these mainly come from trans-boundary water resources [5]. A waterpoor country is defined as a country with less than $1,000 \mathrm{~m}^{3}$ of water per person per year. Sixty percent of people living in water-poor countries globally live in the Mediterranean region. There are considerable inequalities within the region in terms of water availability and the extent of renewable resource use [6]. In the Mediterranean region, water resources are limited, fragile and unevenly distributed over space and time [7]. According to AQUASTAT database [8], in 2009, France, Italy, Spain and Turkey accounted for $67 \%$ of renewable fresh water resources (flows available within their own borders on an annual basis) in the region. The Southern and Eastern Mediterranean countries (SEMCs) accounted for a little more than one-quarter $(27 \%)$ of the region's water resources in 2009. If Turkey is excluded, they accounted for only $6 \%$, yet they are home to $40 \%$ of the region's population [8].

Half of the "water poor" world population (i.e. less than $1,000 \mathrm{~m}^{3}$ per capita per annum) is concentrated in the Southern Mediterranean region [9]. It has been estimated that by 2025 potentially 180 million people will be affected by water problems, 60 million of whom will suffer water shortage of less than $500 \mathrm{~m}^{3}$ per capita per annum [5]. According to AQUASTAT database, the per capita availability of water, including imported quantities, shows similar disparities between northern Mediterranean countries (NMCs) and SEMCs. With the exception of Lebanon and Turkey, less than $1,000 \mathrm{~m}^{3}$ of water is available per person per year in Southern Mediterranean countries. The Balkan states are in a more favourable situation [8].

The water exploitation index for natural renewable freshwater resources is used to measure the relative pressure on those resources arising from their annual use. Exploitation above $40 \%$ of the sustainably available resource indicates a situation of severe water stress. This is the case in Egypt, Libya, Malta, Israel and Syria, where the index exceeds $80 \%$ [10]. Irrigation accounts for almost $65 \%$ of anthropogenic abstraction and can even exceed $80 \%$ in the Southern and Eastern Mediterranean countries [11].

According to the projections of the Blue Plan, which takes the year 2000 as the base year, water demands could increase by a further $15 \%$ by 2025 , especially in the Southern and Eastern countries, where an increase of $25 \%$ is expected. Mariotti et al. [12] have predicted an average decrease of $20 \%$ in surface water availability by 2070-2099. In fact, the impact of climate change on the Mediterranean environment is already noticeable [13]. Pressures will become more severe for the agriculture sector that consumes the largest volume of all water users in the Mediterranean since it accounted for $64 \%$ of overall demand in the period 2005-2010 (49\% in the North, 74 and $81 \%$ in the South and East) [14]. Measures to improve water demand management, water saving and the rational use of water are thus of paramount importance in the region. In fact, the estimated overall water use efficiency for the Mediterranean countries ranges from $50 \%$ to $85 \%$ [11].

One part of the solution to the problem of limited resources and environmental services is to adjust patterns of consumption and production to reduce their demand on these resources. The consumption perspective concentrates on environmental pressures caused by all the products consumed in a country [15]. Fundamental changes in food consumption and production patterns are indispensable for achieving sustainable development. Today, in a context of increasing environmental degradation and climate change, it is clear that a systemic change is needed to move towards resource efficient and sustainable lifestyles.

Diets are a significant factor in a number of critical sustainability issues such as climate change; public health; social inequalities; biodiversity; and energy, land and water use [16]. Everything we consume entails weights of materials or hectares of land, litres of water and quantities of energy which were needed in the production process and that are embodied in products [17] What kind of food is demanded and how much, determine to a large extent how water for agriculture is allocated and used [18].

The global freshwater resources are subject to increasing pressure in the form of consumptive water use and pollution $[19,20]$. According to the Comprehensive Assessment of Water Management in Agriculture [21] the increase in water needed to meet the demand for food is a major concern given the growing water scarcity and environmental problems. Already 1.4 billion people live in places where water is physically scarce [21].

The type, composition and quantity of food that is produced and consumed affects water resources demand (water footprint) [22]. Dietary patterns with high meat and animal products consumption require more energy, water and land resources [18,23,24].

Food supply directly translates into consumptive water use [18]. Consumptive water use refers to the removal of water from a local hydrological system, thereby rendering it unavailable for further use $[25,26]$. Water requirements for plant and animal products vary widely: approximately $0.5 \mathrm{~m}^{3}$ of water is needed to produce $1,000 \mathrm{kcal}$ of plantbased food, while some $4 \mathrm{~m}^{3}$ are required for animal-based food [27].

The water footprint (WF) concept is closely linked to the virtual water (VW) concept [28]. The water footprint and virtual water concepts provide the opportunity to link the use of water resources to the consumption of goods [29]. These concepts have been brought into water management science in order to show the importance of consumption patterns and global dimensions in good water governance [30, 31].

According to Mekonnen and Hoekstra [32], the global water footprint was $9,087 \mathrm{Gm}^{3} / \mathrm{yr}$ in the period 1996-2005. The total volume of international virtual water flows related 
to trade in agricultural and industrial products was 2,320 $\mathrm{Gm}^{3} \mathrm{yr}^{-1}$ of which $76 \%$ is related to crop products trade. Moreover, the water footprint of the global average consumer was $1,385 \mathrm{~m}^{3} / \mathrm{yr}$, of which $92 \%$ is related to agricultural products consumption.

Present consumptive water use for global food production has been estimated at between 16,950 and $18,600 \mathrm{~km}^{3} \mathrm{yr}^{-1}[33,34]$ consisting of green and blue waters [26]. Blue water is derived from surface and groundwater sources whereas green water is derived directly from natural rainfall over agricultural lands. Existing data highlight the dominance of green water in current global food production, even though irrigation accounts for around $70 \%$ of all freshwater withdrawals [20]. However, what is alarming from both a food security and environmental sustainability perspective is that at current rates of agricultural water use efficiency, an estimated additional $5,700 \mathrm{~km}^{3}$ year $^{-1}$ of freshwater will be needed to meet the demand for food in 2050 [34].

Since the availability of additional blue water resources is limited, a range of strategies have been proposed for achieving future food security. These include the continued conversion of natural ecosystems to new agricultural lands to access greater volumes of green water, water productivity improvements in agriculture (i.e. so-called crop per drop improvements), shifting diets to minimize the consumption of animal products which have high consumptive water requirements, water saving through increasing trade in agricultural commodities, and reducing food chain losses [33,34-35,36-37,38].

It is estimated that $30-50 \%$ of all food produced never reaches a human stomach [18,39-40,41-42,43]. This food loss and waste corresponds to more than $10 \%$ of the world's total caloric energy consumption [43]. The amount of food lost or wasted every year is equivalent to more than half of the world's annual cereals crop ( 2.3 billion tons in 2009/10) [44].

In the Near East region, it is estimated that $10-15 \%$ of non-perishables (e.g. grains) and up to $60 \%$ of perishables are lost during the whole production chain. In addition, post-cooking losses are also significant [45]. Total losses in wheat in Egypt, from harvesting until baking, are estimated at $13 \%-15 \%$. Losses that occur in the rice supply chain are about $25 \%$. Estimated losses at the farmer's and merchant's level ranges from $4-10 \%$ for grain and pulses [43]. In Italy, some 20 million tons of food waste are formed every year throughout the supply chain. Every French citizen throws away $7 \mathrm{~kg}$ of food every year that is still in the original package [46].

Trends in diet composition towards a higher proportion of animal food items, fruit and vegetables tend to shorten the durability of food and could increase the risk of losses and wastage [18]. Fruit and vegetables as well as roots and tubers have the highest wastage rates of any food [44]. Distance to market, a more complex food chain and changes in composition and variety of food supply provide opportunities for more food and water wastage [18].
Food wastage and loss amount to loss of water and other precious natural resources. Reducing food loss and wastage reduces water needs in agriculture [18] as well as environmental impacts [18,38].

The paper aims at analyzing the water footprint of food consumption and implications of food waste in terms of water demand and use.

\section{Material and Methods}

The work is based on an extended review of secondary data from different sources especially FAOSTAT and the Water Footprint Network. The geographical coverage of this study is similar to that of the Mediterranean Strategy for Sustainable Development (MSSD) [47] including 21 countries around the Mediterranean. The main groups are:

- The Northern Mediterranean Countries (NMC): Cyprus (CY), Spain (ES), France (FR), Greece (GR), Italy (IT) and Malta (MT).

- The Balkan Countries (BC): Albania (AL), Bosnia and Herzegovina (BA), Croatia (HR), Montenegro (ME), and Slovenia (SI).

- The Southern and Eastern Mediterranean Countries (SEMC): North Africa (Algeria (DZ), Egypt (EG), Libya (LY), Morocco (MA), Tunisia (TN)), Eastern Mediterranean countries (Israel (IL), Lebanon (LB), Palestinian territories (PS), Syria (SY)) and Turkey (TR).

The UE-28 Mediterranean countries gather 8 countries: Croatia, Cyprus, Spain, France, Greece, Italy, Malta and Slovenia. In addition to these countries data were collected as well for Portugal (PT), Serbia (SR) and Macedonia (MK).

Secondary data from the Water Footprint Network were used to analyze water footprints of consumption and virtual water balances in the Mediterranean. Regarding definitions of the WF, the Water Footprint Network's Global Water Footprint Standard is used [48]. The water footprint (WF) is the demand of freshwater resources required to produce goods and services and it represents a measure of human's appropriation of freshwater resources: freshwater appropriation is measured in terms of water volumes consumed (evaporated or incorporated into a product) or polluted per unit of time. The water footprint includes the use of blue water (ground and surface water), green water (rain water or moisture stored in soil strata), and grey water. The grey water footprint refers to pollution and is defined as the volume of freshwater that is required to assimilate the load of pollutants given natural background concentrations and existing ambient water quality standards [48]. The water footprint of consumption of a country is defined as the total volume of freshwater that is used to produce the goods consumed by its inhabitants. It is the sum of direct and indirect water use of domestic and foreign water resources through domestic consumption [49]. The paper analyses as well food-related water use economic efficiency expressed as water footprint of food 
supply per monetary unit of output $\left(\mathrm{m}^{3} / \mathrm{GDP}\right)$. Differences between North Africa, Middle East, the Balkans, the North Mediterranean, North Europe (Finland) and North America (USA) were analyzed.

FAO Food Balance Sheets were used to characterize the Mediterranean dietary patterns (MDPs). Data regarding the western dietary patterns (WD), exemplified by the U.S.A. and Finland food consumption patterns, were obtained as well from the FAO Food Balance Sheets [50].

Water footprints of food supply were calculated for 5 Mediterranean countries: Bosnia, Egypt, Italy, Morocco, and Turkey. The methodology used in this paper for the calculation of the water footprint of national food supply is similar to that used by [51] in their analysis of the environmental footprint of the Spanish dietary pattern. Water footprints of crops and derived crop products as well as farm animals and animal products were obtained from the main report of Mekonnen and Hoekstra [22,52]. Water footprint of food supply in each country was calculated using average water footprint per ton of commodity per country, weighted based on origin [32]. Adopting a consumption perspective, the paper identifies the consumed food products driving pressure on water resources in the five Mediterranean countries and makes comparison with Northern Europe (Finland) and North America (USA). The main problems faced were related to the availability of and/or the accessibility to footprints of food products or food product groups. There were also some difficulties regarding the management and processing of data and some simplification was necessary. According to Zessner et al. [53], the conversion of food product supply values (as given by the FAO Food Balance Sheets) to actual consumption values implies two correction factors: the first factor accounts for food components not eaten and the second for food waste and feed to domestic animals.

\section{Results and Discussion}

\subsection{Water Footprint of Consumption and Virtual Water Balance in the Mediterranean}

\subsubsection{Water Footprint of Food Consumption}

Data from the 1996-2005 period show that the WF of consumption varies widely amongst Mediterranean countries (Table 1), especially in terms of internal and external WF of consumption. In fact, the share of the external WF of consumption ranged from $7.3 \%$ to $91.8 \%$ in Palestine and Malta, respectively. The water footprint of national consumption ranges between $1055 \mathrm{~m}^{3}$ per year and per capita in Palestine and $2505 \mathrm{~m}^{3}$ per year and per capita in Portugal. Northern Mediterranean countries have higher water footprints of consumption per year and per capita compared to SEMC and the Balkans. The per capita water footprints in the Mediterranean, especially in Southern and Eastern Mediterranean countries, are lower than those recorded in North America but higher than the water footprint of consumption of Finnish citizens.
Table 1. Water footprint of national consumption [32]. NA: North America; NE: North Europe. Data are not available for Montenegro.

\begin{tabular}{|c|c|c|}
\hline Region & Country & $\begin{array}{c}\text { WF of national consumption } \\
\left(\mathrm{m}^{3} / \text { year/per capita) }\right.\end{array}$ \\
\hline \multirow{11}{*}{$\begin{array}{l}\text { Southern and } \\
\text { Eastern } \\
\text { Mediterranean } \\
\text { countries }\end{array}$} & Palestine & 1055 \\
\hline & Egypt & 1341 \\
\hline & Algeria & 1589 \\
\hline & Turkey & 1642 \\
\hline & Jordan & 1678 \\
\hline & Morocco & 1725 \\
\hline & Libya & 2038 \\
\hline & Syria & 2107 \\
\hline & Lebanon & 2112 \\
\hline & Tunisia & 2217 \\
\hline & Israel & 2303 \\
\hline \multirow{6}{*}{ Balkans } & Bosnia & 1256 \\
\hline & Macedonia & 1348 \\
\hline & Albania & 1555 \\
\hline & Croatia & 1688 \\
\hline & Slovenia & 2012 \\
\hline & Serbia & 2390 \\
\hline \multirow{7}{*}{$\begin{array}{l}\text { Northern } \\
\text { Mediterranean } \\
\text { countries }\end{array}$} & France & 1786 \\
\hline & Malta & 2216 \\
\hline & Italy & 2303 \\
\hline & Greece & 2338 \\
\hline & Cyprus & 2385 \\
\hline & Spain & 2461 \\
\hline & Portugal & 2505 \\
\hline NA & North America & 2588 \\
\hline NE & Finland & 1414 \\
\hline
\end{tabular}

Table 2. Total water footprint of agricultural products consumption [32]. Data are not available for Montenegro.

\begin{tabular}{cccc}
\hline Country & $\mathbf{( \% )}$ & Country & $\mathbf{( \% )}$ \\
\hline Serbia & 61.8 & Croatia & 93.0 \\
Macedonia & 84.0 & Libya & 93.3 \\
Slovenia & 85.0 & Lebanon & 93.6 \\
Albania & 86.0 & Spain & 93.7 \\
France & 86.9 & Portugal & 94.0 \\
Italy & 89.4 & Israel & 94.1 \\
Cyprus & 89.4 & Jordan & 94.9 \\
Malta & 90.2 & Bosnia & 94.9 \\
Egypt & 90.5 & Syria & 95.0 \\
Greece & 90.7 & Algeria & 97.2 \\
Turkey & 91.9 & Morocco & 97.6 \\
Palestine & 92.8 & Tunisia & 97.7 \\
\hline
\end{tabular}

Most of the WF of consumption is due to the consumption of agricultural products (Table 2). The share of the water footprint of agricultural products consumption 
in the total water footprint of consumption ranges from $61.8 \%$ in Serbia to $97.7 \%$ in Tunisia. The average value is approximately $91 \%$ of the total WF of consumption.

Table 3. Water use economic efficiency in Italy, Bosnia, Morocco, Egypt and Turkey. Data regarding National total WF [32] and GDP [54] refer to 2005.

\begin{tabular}{cc}
\hline Country & WF/GDP $\left(\mathbf{m}^{3} / \mathbf{m i l l i o n} \$\right)$ \\
\hline Italy & $74,159.75$ \\
Bosnia & $423,840.19$ \\
Morocco & $839,330.17$ \\
Egypt & $1,060,987.65$ \\
Turkey & $227,268.80$ \\
\hline
\end{tabular}

\subsubsection{Economic Efficiency of Water Use in Italy, Bosnia,} Morocco, Egypt and Turkey

The highest is the WF/GDP ratio the lowest is the economic efficiency of water use in a country. Water resources use economic efficiency changes from a country to another. The highest economic efficiency of water use is recorded in Italy followed by Turkey while the lowest is recorded in Egypt (Table 3).

\subsubsection{Virtual Water Balance}

Mekonnen and Hoekstra [32] also evaluated the virtual water balance in the period from 1995 to 2005 (Figure 1) based on an assessment of virtual-water flows related to trade in crop, animal and industrial products. Only Tunisia, Syria and Serbia present a negative total net virtual water balance. The other Mediterranean countries have a positive net virtual water balance. This is due to the fact that most of Mediterranean countries are not self-sufficient for many products so they import them thus import also virtual water. The other Mediterranean countries show water savings ranging from $340 \mathrm{Mm}^{3}$ to $62,157 \mathrm{Mm}^{3}$, in Macedonia and Italy, respectively. This can be explained by the fact that the production of agricultural/industrial goods is very water efficient in NMC as compared to the other SEMC countries i.e. virtual water contents of goods are relatively lower.

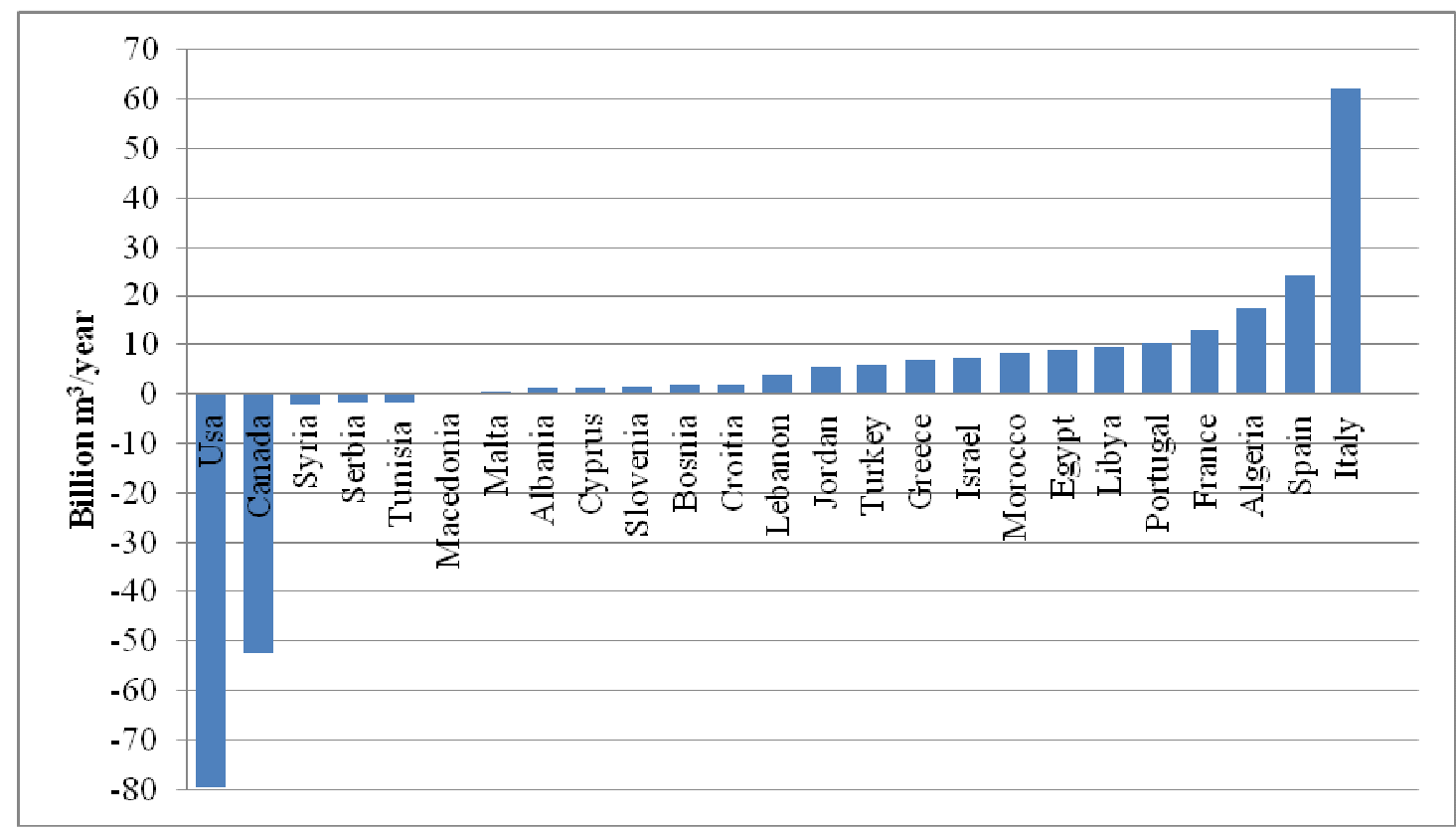

Figure 1. Net virtual water balance ( $\mathrm{Mm}^{3} /$ year) [32]. Data are not available for Montenegro and the Palestinian territories.

\subsection{Food Supply in the Mediterranean Region}

According to the FAO [50], in 2009 dietary energy in the Mediterranean ranged between 2130 in Palestine and 3666 $\mathrm{kcal} / \mathrm{day} /$ person in Turkey. In general, dietary energy is higher in northern Mediterranean countries. FAO Food Balance Sheets show that dietary energy increased in the period 1990-2009 in all the Southern and Eastern Mediterranean countries except in Libya, the Palestinian territories and Turkey. The share of plant-based energy in the diet in the Mediterranean is generally higher than $50 \%$. In general, it is higher in eastern and southern Mediterranean countries with respect to northern ones while intermediate values are recorded in the Balkans. The share of plant-based energy in the diet is higher in the
Mediterranean than in Northern Europe and America. Taking into consideration 2009 data, the shares of vegetalbased energy in the diet ranged from $66.5 \%$ in France to $88.8 \%$ in the Palestinian Territories. The largest share of plant-based energy is derived from cereals. In general, that share is higher than in northern Europe and North American (e.g. USA). Moreover, in most of the Mediterranean countries the contribution of vegetal-based products to the total dietary energy decreased between 1990 and 2009 (Table 4).

According to Vanham et al. [29], for a healthy diet in the EU28 (EU27 and Croatia), including Northern Mediterranean countries, the intake of some product groups (sugar, crop oils, meat and animal fats) should be reduced and of other product groups (vegetables and fruit) increased. 
Dairy products are the most consumed foods in Italy, while in North African countries (Egypt and Morocco) the most consumed food item are cereals. A different situation exist $\mathrm{n}$ Bosnia and Turkey where vegetables are at the top of the list of consumed food products.

Table 4. Trend of dietary energy and the shares of vegetal-based energy in the diet in the Mediterranean countries [50]. In case data for 1990 are not available the reference year is put in brackets after the country name.

\begin{tabular}{|c|c|c|c|c|c|c|c|c|}
\hline \multirow{3}{*}{ Country } & \multicolumn{3}{|c|}{ Food supply (Kcal/capita/day) } & \multicolumn{4}{|c|}{ Vegetal products } & \multirow{3}{*}{$\begin{array}{c}\text { Change of the } \\
\text { contribution of vegetal- } \\
\text { based products to the } \\
\text { total dietary energy } 1990 \text { - } \\
2009(\%)\end{array}$} \\
\hline & \multirow{2}{*}{1990} & \multirow{2}{*}{2009} & \multirow{2}{*}{$\begin{array}{c}\text { Change in the } \\
\text { period 1990- } \\
2009(\%)\end{array}$} & \multicolumn{2}{|l|}{1990} & \multicolumn{2}{|l|}{2009} & \\
\hline & & & & Kcal/capita/day & $\%$ & Kcal/capita/day & $\%$ & \\
\hline Albania & 2656 & 2903 & 9.3 & 2188 & 82.38 & 2042 & 70.34 & -12.04 \\
\hline Algeria & 2855 & 3239 & 13.5 & 2536 & 88.83 & 2886 & 89.10 & 0.27 \\
\hline Croatia (1992) & 2412 & 3130 & 29.8 & 1839 & 76.24 & 2291 & 73.19 & -3.05 \\
\hline Cyprus & 2685 & 2678 & -0.003 & 1952 & 72.70 & 1981 & 73.97 & 1.27 \\
\hline Egypt & 3154 & 3349 & 6.2 & 2944 & 93.34 & 3061 & 91.40 & -1.94 \\
\hline France & 3515 & 3531 & 0.5 & 2180 & 62.02 & 2348 & 66.50 & 4.48 \\
\hline Greece & 3539 & 3661 & 3.4 & 2792 & 78.89 & 2808 & 76.70 & -2.19 \\
\hline Italy & 3584 & 3627 & 1.2 & 2649 & 73.91 & 2694 & 74.28 & 0.36 \\
\hline Lebanon & 2965 & 3153 & 6.3 & 2555 & 86.17 & 2616 & 82.97 & -3.20 \\
\hline Libya & 3222 & 3157 & -2.0 & 2789 & 86.56 & 2765 & 87.58 & 1.02 \\
\hline Macedonia (1992) & 2418 & 2957 & 22.3 & 1974 & 81.64 & 2410 & 81.50 & -0.14 \\
\hline Malta & 3078 & 3438 & 0.12 & 2300 & 74.72 & 2530 & 73.59 & -1.13 \\
\hline $\begin{array}{l}\text { Montenegro } \\
(2006)\end{array}$ & 2681 & 2887 & 7.7 & 1918 & 71.54 & 2084 & 72.19 & 0.65 \\
\hline Morocco & 3073 & 3264 & 6.2 & 2864 & 93.20 & 2988 & 91.54 & -1.65 \\
\hline $\begin{array}{l}\text { Palestinian } \\
\text { Territories (1996) }\end{array}$ & 2321 & 2130 & -8.2 & 2036 & 87.72 & 1893 & 88.87 & 1.15 \\
\hline Portugal & 3393 & 3617 & 0.07 & 2601 & 76.66 & 2563 & 70.86 & -5.80 \\
\hline Serbia (2006) & 2696 & 2823 & 4.7 & 2079 & 77.11 & 2204 & 78.07 & 0.96 \\
\hline Spain & 3279 & 3239 & -1.2 & 2449 & 74.69 & 2413 & 74.50 & -0.19 \\
\hline Syria & 2896 & 3212 & 10.9 & 2524 & 87.15 & 2750 & 85.62 & -1.54 \\
\hline Tunisia & 3124 & 3314 & 6.1 & 2853 & 91.33 & 2966 & 89.50 & -1.83 \\
\hline Turkey & 3766 & 3666 & -2.7 & 3353 & 89.03 & 3240 & 88.38 & -0.65 \\
\hline
\end{tabular}

\subsection{Water Footprint of Food Supply in Italy, Bosnia, Morocco, Egypt and Turkey}

\subsubsection{Total Water Footprint of Food Supply}

Among the five considered Mediterranean countries, the lowest water footprint of food supply is that recorded in Egypt while the highest is recorded in Bosnia, which is slightly higher than that recorded in Italy. The average water footprint of an Italian citizen is $35.36 \%, 30.12 \%$, $11.01 \%$ higher and $0.08 \%$ lower than that of an Egyptian, a Turkish, a Moroccan and a Bosnian one, respectively. Regarding the Southern Mediterranean countries, the average water footprint in Morocco is $37.68 \%$ higher than the one recorded in Egypt. The total water footprint of food supply in the USA is higher than in the other five Mediterranean countries while the Finnish water footprint is lower (Table 5).
Table 5. Total water footprint of food supply in Italy, Bosnia, Morocco, Egypt, Turkey, the USA and Finland; 2006.

\begin{tabular}{cc}
\hline Country & Total WF of food supply $\left(\mathbf{m}^{3} /\right.$ capita/year $)$ \\
\hline USA & 2198,66 \\
Bosnia & 1849,70 \\
Italy & 1848,29 \\
Morocco & 1644,85 \\
Turkey & 1291,65 \\
Egypt & 1194,70 \\
Finland & 1116,69 \\
\hline
\end{tabular}

Vanham et al. [29] and Vanham and Bidoglio [49] found that the total current EU28 (EU27 and Croatia) water footprint of consumption (WFcons) is 4815 litres per capita per day (lcd) (i.e. $1757.47 \mathrm{~m} 3 /$ capita/year). Of the latter $40 \%$ 
is external to Europe. The WF of agricultural products contributes by far the largest fraction $(89 \%)$ of the total water footprint of consumption [49]. Edible products account for the largest fraction of the total WFcons i.e. 4032 lcd (1471.7 $\mathrm{m} 3 /$ capita/year). This shows that the largest reductions in the WFcons can be made by changing diets [29].

\subsubsection{Green, Blue and Grey Water Footprint of Food Supply}

The shares of the three components of the water footprint change from a country to another. In all the Mediterranean countries, except for Egypt, the highest water footprint is the green one, followed by the grey for Bosnia and Italy and the blue one in the case of Morocco and Turkey. As for Egypt, the first component is the blue one while the green one is ranked second. The highest share of the blue water component in the total water footprint is recorded in Egypt which is due mainly to the fact that water is used in irrigation (Table 6).

Table 6. Green, blue and grey water footprints of food supply in Italy, Bosnia, Morocco, Egypt, and Turkey; 2006.

\begin{tabular}{cccc}
\hline Country & Green (\%) & Grey (\%) & Blue (\%) \\
\hline Egypt & 40.3 & 17.7 & 42.0 \\
Turkey & 80.6 & 8.2 & 11.2 \\
Morocco & 83.4 & 4.5 & 12.1 \\
Italy & 84.0 & 8.8 & 7.2 \\
Bosnia & 88.0 & 9.0 & 3.0 \\
\hline
\end{tabular}

\subsubsection{Food Product Groups Contribution to the Total Water Footprint of Food Supply}

The meat products group contribution to the total water footprint is the highest in Bosnia and Italy where, more or less, a third of the total water footprint is due to meat products consumption. While cereals contribution to the total water footprint is the highest in Southern and Eastern Mediterranean countries (Egypt, Morocco and Turkey), where they are responsible of more than a third of virtual water use. The contribution of vegetable oils (e.g. olive oil) to the water footprint is relevant in Italy but not in the other countries. When considering both meat and dairy products they represent more than a half of the total water footprint of food supply in Bosnia and Italy (Table 7).

Red meat is the food with greatest impact, while fruit and vegetables have decidedly limited footprints [55,56,57]. In general, lower is the animal products consumption (especially beef meat) lower is the environmental impact. Meat production has high environmental impacts $[58,59,60]$. According to Vanham et al. [29] especially the consumption of animal products accounts for high WF amounts.

Due to the numerous negative impacts of an intensive livestock production system on the planet's resources and ecosystems, moving to a more resource-efficient (and healthier) vegetable-rich diet is a necessity [49]. The livestock industry is one of the largest contributors to environmental degradation, at local and global scale $[61,62]$.
Table 7. Food product groups contribution to the total water footprint of food supply in Italy, Bosnia, Morocco, Egypt, and Turkey; 2006.

\begin{tabular}{|c|c|c|c|c|c|}
\hline & Bosnia & Italy & Turkey & Morocco & Egypt \\
\hline Meat & 31.81 & 39.62 & 16.57 & 27.28 & 31.51 \\
\hline Vegetable Oils & 4.01 & 14.54 & 7.35 & 5.68 & 1.81 \\
\hline Milk & 21.92 & 12.22 & 12.56 & 7.60 & 6.29 \\
\hline Cereals & 9.13 & 11.01 & 40.07 & 37.56 & 33.42 \\
\hline Stimulants & 10.03 & 6.84 & 2.15 & 2.78 & 0.40 \\
\hline Fruit & 5.97 & 3.62 & 4.49 & 4.92 & 6.80 \\
\hline $\begin{array}{ll}\text { Sugar } & \& \\
\text { Sweeteners } & \end{array}$ & 4.57 & 3.10 & 3.12 & 2.56 & 3.85 \\
\hline $\begin{array}{l}\text { Alcoholic } \\
\text { Beverages }\end{array}$ & 2.30 & 1.99 & 0.39 & 0.20 & 0.14 \\
\hline Animal Fats & 2.18 & 1.88 & 1.00 & 2.53 & 1.39 \\
\hline Vegetables & 2.47 & 1.87 & 3.48 & 1.88 & 5.31 \\
\hline Offals & 0.84 & 1.01 & 0.54 & 0.99 & 2.40 \\
\hline Others & 4.78 & 2.31 & 8.30 & 6.03 & 6.68 \\
\hline Eggs & 0.31 & 0.80 & 3.06 & 2.87 & 0.86 \\
\hline Oil crops & 0.11 & 0.56 & 2.36 & 0.31 & 1.89 \\
\hline Pulses & 2.02 & 0.46 & 2.00 & 2.05 & 1.78 \\
\hline Starchy Roots & 0.04 & 0.42 & 0.60 & 0.49 & 0.85 \\
\hline Spices & 0.00 & 0.07 & 0.29 & 0.30 & 0.66 \\
\hline Sugar crops & 0.00 & 0.00 & 0.00 & 0.00 & 0.64 \\
\hline
\end{tabular}

Table 8. Top ten contributing products to food supply water footprint (\%) in Italy and Turkey; 2006.

\begin{tabular}{lclc}
\hline item & Italy & item & Turkey \\
\hline Bovine meat & 14.0 & Wheat & 37.0 \\
Milk & 12.2 & Milk & 12.6 \\
Wheat & 10.2 & Bovine meat & 8.0 \\
Coffee & 5.1 & Poultry meat & 5.9 \\
Poultry meat & 1.9 & Sunflower seed oil & 1.8 \\
Cocoa beans & 1.7 & Maize & 1.1 \\
Sunflower seed oil & 1.3 & Coffee & 0.9 \\
Offals & 1.0 & Potatoes & 0.6 \\
Potatoes & 0.4 & Offals & 0.5 \\
Maize & 0.2 & Cocoa Beans & 0.5 \\
\hline
\end{tabular}

With traditional water use statistics, awareness campaigns and policy have always focused on increasing water efficiency in domestic and industrial water use. However, much more water can be saved in agricultural production processes, by reducing food waste and by a change in diet [49].

The top ten products contributing to the total water footprint of food supply change from a country to another. Wheat is the first of the list in the case of Egypt, Morocco and Turkey, while the top products are bovine meat for Italy and milk for Bosnia. In the case of Italy (Table 8), the top ten products are, in descending order: bovine meat, milk, wheat, coffee, poultry meat, cocoa beans, sunflower seed oil, offals, potatoes and maize. 


\subsection{Implications of Food Wastage in Terms of Water Use}

Food and drink wastage involves major global environmental consequences. Food loss and wastage amount to major squandering of resources, including water, land, energy, labour and capital, and needlessly produce greenhouse gas emissions [44,63]. Food loss and waste account for more than one quarter of the total consumptive use of finite and vulnerable freshwater and more than 300 million barrels of oil per year [64]. The long food products journey - "from cradle to grave" - involves a consumption of resources, labour, and, consequently, of greenhouse gas emissions. So, when considering a foodstuff throughout its life cycle, one must also take into account the water, energy, and resources consumed, and, therefore, wasted when this food becomes refuse [65].

Wasting food means losing not only life-supporting nutrition but also precious resources, including land, water and energy. Food losses and waste imply that large amounts of land, energy, fertilisers and water have also been lost in the production of foodstuffs which simply end up as waste [39]. Transitioning to more sustainable diets and minimizing waste can also reduce demand for water; a 50\% decrease in food losses and waste at the global level would save $1,350 \mathrm{~km}^{3}$ a year [66].

A recent study carried out by WWF Italia [67] analyzed the environmental footprints of food waste in Italy, in particular the water footprint. The study has shown that in Italy in 2012, 706 million $\mathrm{m} 3$ of water are associated with the waste of meat, cereals, fruits and vegetables, tubers and roots, and milk by Italian consumers. The contribution to water wastage changes from a food product group to another: $43 \%$ of water wasting is due to the wastage of meat and meat products, $34 \%$ to cereals and bakery products, $16 \%$ to fruits and vegetables, $3 \%$ to roots and tubers, and $4 \%$ is associated to milk and dairy products wastage.

Reducing the amount of food wasted throughout the food chain in the entire Mediterranean area would help improving food and nutrition security and contribute to easing pressure on natural resources especially water. Reducing waste across the whole food system will increase the amount of food available for human consumption for the given level of inputs, thereby improving input use efficiency [68]. Making the food chain more efficient through waste reduction measures will reduce pressure on resources required for food production, lower greenhouse gas emissions [4].

It is estimated that 600 litres of water are wasted per capita and per day that's to say $2,400,000 \mathrm{~m}^{3} \mathrm{day}^{-1}$ in the whole Apulia region, south-eastern Italy (i.e. 876,000,000 $\mathrm{m}^{3}$ year $\left.{ }^{-1}\right)$. This corresponds to the volume of water that is used yearly in irrigation in the whole region (Lamaddalena $\mathrm{N}$, personal communication).

Interventions to reduce food chain waste will likely have as great or even greater impact on freshwater resource availability as other water use efficiency measures in agriculture and food production [3]. Reducing post-harvest waste can be achieved through: deployment of existing knowledge and technology in storage and transport infrastructure, investment in new, appropriate technology to reduce post-harvest waste; and infrastructure, financial and market reforms to reduce waste. Meanwhile, for reducing waste by consumers and the food service sector many actions are needed: campaigns to highlight the extent of waste and the financial benefits of reducing it; the development and use of cheap, mass-produced sensor technology that can detect spoilage in certain perishable foods; productive recycling of surplus food deemed as nonpremium quality; spreading best practice, etc. [4].

\section{Conclusions}

Food consumption has significant impacts on the scarce Mediterranean natural resources. Moreover, population increase, especially in the southern and eastern Mediterranean countries, will increase pressure on the region's limited natural resources, particularly water. In fact, almost $65 \%$ of water resources in the Mediterranean are used in irrigation.

The WF of consumption varies widely amongst Mediterranean countries especially in terms of internal and external WF of consumption. Northern Mediterranean countries had the highest water footprint of consumption per year and per capita in the region. Generally, the per capita water footprints in the Mediterranean are lower than those recorded in North Europe and North America. Approximately $91 \%$ of the total WF of consumption is due to the consumption of agricultural products in the Mediterranean region. Most of the Mediterranean countries have a negative net virtual water balance i.e. they have water savings. The economic efficiency of water use (water footprint per GDP) in Italy is higher than those recorded in Turkey, Bosnia, Morocco and Egypt.

In 2009, dietary energy in the Mediterranean ranged between 2130 in Palestine and $3666 \mathrm{kcal} /$ day/person in Turkey. Generally speaking, dietary energy increased in the period 1990-2009 in Southern and Eastern Mediterranean countries. The share of plant-based energy in the diet in the Mediterranean is generally higher than $50 \%$ but it decreased between 1990 and 2009.

The lowest water footprint of foot supply among the five considered Mediterranean countries is that recorded in Egypt while the highest is recorded in Bosnia. The average water footprint of an Italian citizen is $35.36 \%$ higher than that of an Egyptian one and $0.08 \%$ lower than that of a Bosnian citizen while it is $15.94 \%$ lower than that of a North American one. The average water footprint in Morocco is $37.68 \%$ higher than the one recorded in Egypt. The green component is the most relevant one followed by the grey one in the case of Bosnia and Italy and by the blue one for Turkey and Morocco. In Egypt, the blue component is the most relevant one followed by the green one. Meat, wheat and dairy products represent in all the five Mediterranean countries more than a half of the total water footprint of food supply. 
The contribution of meat and dairy products is higher in Bosnia and Italy with respect to the three SEMC. More than a third of the water footprint is due to the supply of cereals in Egypt, Morocco and Turkey. The top contributors to the total water footprint of food supply in Italy are bovine meat, milk, wheat, coffee and poultry meat.

Adoption of more sustainable food consumption patterns and production systems and the reduction of food losses and waste can help reducing pressure on natural resources in the Mediterranean especially water. Reducing waste across the whole food system will increase input use efficiency. Interventions to reduce food chain waste will likely have an impact similar or greater than other water use efficiency measures in agriculture and food production. The potential to make more food available by simply eliminating losses, while simultaneously freeing up water resources for other uses, is an opportunity that should not be ignored and should be put high on the Mediterranean policy and research agenda. Therefore, there is an urgent need to design and implement appropriate policies, supported by research activities, to foster the changes necessary to make the current Mediterranean food consumption patterns more sustainable.

It is also important to assess the environmental sustainability of the Mediterranean food consumption patterns taking into consideration at the same time all the environmental footprints (e.g. water footprint, ecological footprint, carbon footprint, nitrogen footprint, and energy footprint). The production of waste is another factor that should be considered for a more accurate assessment of diets environmental sustainability.

\section{References}

[1] J. Bartram, "Improving on haves and have-nots," Nature 452 (7185), pp. 283-284, 2008.

[2] M. Falkenmark, "Water and sustainability: a reappraisal. Environment," 50, vol. 2, pp. 4-16, 2008.

[3] B.G. Ridoutt, P. Juliano, P. Sanguansri, and J. Sellahewa, "Consumptive water use associated with food waste: case study of fresh mango in Australia," Hydrology and Earth System Sciences Discussions, vol. 6, pp. 5085-5114, 2009.

[4] Foresight, The Future of Food and Farming: Challenges and choices for global sustainability. Executive Summary. The Government Office for Science, London, 2011.

[5] UNEP/MAP-Plan Bleu, State of the Environment and Development in the Mediterranean. UNEP/MAP-Plan Bleu, Athens, 2009.

[6] FAO, State of Mediterranean Forests 2013. Rome, 2013.

[7] Blue Plan, Facing water stress and shortage in the Mediterranean. Blue Plan Notes $\mathrm{n}^{\circ} 4$, Environment and Development in the Mediterranean. Sophia Antipolis, Valbonne, 2006.
[8] AQUASTAT, AQUASTAT database. FAO, 2012. Available at: http://www.fao.org/nr/water/aquastat/main/index.stm.

[9] Mediterra, The future of agriculture and food in Mediterranean countries. International Centre for Advanced Mediterranean Agronomic Studies and Blue Plan, Hervieu B. (ed.), Editori Laterza, Bari (Italy), 2008.

[10] B. Ewing, D. Moore, S. Goldfinger, A. Oursler, A. Reed, and M. Wackernagel, The Ecological Footprint Atlas 2010. Global Footprint Network, Oakland, 2010.

[11] G. Thivet, and M. Blinda, Améliorer l'efficience d'utilisation de l'eau pour faire face aux crises et pénuries d'eau en Méditerranée. Plan Bleu, Sophia-Antipolis, 2007

[12] A. Mariotti, N. Zeng, J. Yoon, V. Artale, A. Navarra, P. Alpert, Z. Li, and X. Laurent, Mediterranean water cycle changes: transition to drier 21 st century conditions in observations and CMIP3 simulations. Environmental Research Letters, 3, 2008. doi:10.1088/17489326/3/4/044001.

[13] Blue Plan, The Blue Plan's Sustainable Development Outlook for the Mediterranean. UNEP Blue Plan Activity Centre, Sophia Antipolis, Valbonne, 2008.

[14] D. Molden, T.Y. Oweis, P. Steduto, J.W. Kijne, M.A. Hanjra, P.S. Bindraban, B.A.M. Bouman, S. Cook, O. Erenstein, H. Farahani, A. Hachum, J. Hoogeveen, H. Mahoo, V. Nangia, D. Peden, A. Sikka, P. Silva, H. Turral, A. Upadhyaya, S. Zwart, Pathways for increasing agricultural water productivity. In Comprehensive Assessment of Water Management in Agriculture: Water for Food, Water for Life. Molden, D. (eds.), International Water Management Institute, London Earthscan, Colombo, 2007.

[15] European Environment Agency, Environmental pressures from European consumption and production: a study in integrated environmental and economic analysis. EEA Technical report No 2/2013, Copenhagen.

[16] Sh. Reddy, T. Lang, and S. Dibb, Setting the table - Advice to Government on priority elements of sustainable diets, Sustainable Development Commission, UK, 2009.

[17] GLOBAL 2000, SERI, Friends of the Earth Europe, Hidden impacts: How Europe's resource overconsumption promotes global land conflicts. Umweltschutzorganisation GLOBAL 2000, Sustainable Europe Research Institute (SERI), Friends of the Earth Europe. Vienna, 2013.

[18] J. Lundqvist, C. de Fraiture, and D. Molden, Saving water: From field to fork. Policy Brief, Stockholm International Water Institute, 2008.

[19] S.L. Postel, "Entering an era of water scarcity: the challenges ahead," Ecological Applications, 10, vol. 4, pp. 941-948. 2000.

[20] UNESCO-WWAP, Water: a shared responsibility. The United Nations World Water Development Report 2, United Nations Educational Scientific and Cultural OrganizationWorld Water Assessment Programme, UNESCO Publishing, Paris/Berghahn Books, New York, 2006.

[21] CA, Water for food, water for life: a comprehensive assessment of water management in agriculture. International Water Management Institute (IWMI), Earthscan, London and Colombo, 2007. 
[22] M.M. Mekonnen, and A.Y. Hoekstra, The green, blue and grey water footprint of crops and derived crop products. Value of Water Research Report Series No. 47, UNESCOIHE, Delft, the Netherlands, 2010a. Available online at: http://www.waterfootprint.org/Reports/Report47WaterFootprintCrops-Vol1.pdf

[23] D. Pimentel, and M. Pimentel, "Sustainability of meat-based and plant-based diets and the environment," Am. J. Clin. Nutr., 78, vol. 3, pp. 660s-663s, 2003.

[24] W. Gerbens-Leenes, and S. Nonhebel, "Food and land use. The influence of consumption patterns on the use of agricultural resources," Appetite, 45, pp. 24-31, 2005.

[25] M. Falkenmark, and M. Lannerstad, "Consumptive water use to feed humanity - curing a blind spot," Hydrol. Earth Syst. Sci., 9, pp.15-28, 2005.

[26] J.G. Liu, A.J.B. Zehnder, and H. Yang, "Global consumptive water use for crop production: the importance of green water and virtual water," Water Resour. Res., 45, W05428, 2009. doi:10.1029/2007WR006051.

[27] M. Falkenmark, and J. Rockström, Balancing water for humans and nature: the new approach in ecohydrology. Earthscan Publications, London, 2004.

[28] A.Y. Hoekstra, and A.K. Chapagain, "Water footprints of nations: water use by people as a function of their consumption pattern," Water Resources Management, 21, pp.35-48, 2007.

[29] D. Vanham, M.M. Mekonnen, and A.Y. Hoekstra, "The water footprint of the EU for different diets," Ecological Indicators ,32, pp.1-8, 2013.

[30] A. Galli, T. Wiedmann, E. Ercin, D. Knoblauch, B. Ewing, and S. Giljum, "Integrating ecological, carbon and water footprint into a "footprint family" of indicators: definition and role in tracking human pressure on the planet," Ecol. Ind., 16, pp.100-112, 2012.

[31] A.Y. Hoekstra, and A.K. Chapagain, Globalization of Water - Sharing the Planet's Freshwater Resources. Blackwell Publishers, Malden, Oxford, Carlton, 2008.

[32] M.M. Mekonnen, and A.Y. Hoekstra, National water footprint accounts: the green, blue and grey water footprint of production and consumption. Value of Water Research Report Series No. 50, UNESCO- Institute for Water Education (IHE), Delft, The Netherlands, 2011.

[33] J. Rockström, M. Lannerstad, and M. Falkenmark, "Assessing the water challenge of a new green revolution in developing countries,” P. Natl. Acad. Sci. USA, 104, vol.15, pp. 6253-6260, 2007.

[34] J. Rockström, M. Falkenmark, L. Karlberg, H. Hoff, S. Rost, and D. Gerten, Future water availability for global food production: the potential of green water for increasing resilience to global change. Water Resour. Res. 45, W00A12, 2009. doi:10.1029/2007WR006767.

[35] J. Lundqvist, J. Barron, G. Berndes, A. Berntell, M. Falkenmark, L. Karlberg, and J. Rockstöm, Water pressure and increases in food and bioenergy demand implications of economic growth and options for decoupling. In: Scenarios on Economic Growth and Resource Demand, Swedish Environmental Advisory Council, Ministry of the Environment, Stockholm. 2007.
[36] J. Liu, and H.H.G. Savenije, "Food consumption patterns and their effect on water requirement in China," Hydrol. Earth Syst. Sci., 12, pp. 887-898, 2008.

[37] J.G. Liu, H. Yang, and H.H.G. Savenije, "China's move to higher-meat diet hits water security," Nature, 454 (7203), pp.397, 2008 .

[38] C. Nellemann, M. MacDevette, T. Manders, B. Eickhout, B.Svihus, A.G. Prins, and B.P. Kaltenborn, (eds.), The environmental food crisis: the environment's role in averting future food crises. UNEP rapid response assessment, United Nations Environment Programme, UNEP/GRID-Arendal, Arendal, Norway, 2009.

[39] Institution of Mechanical Engineers-UK, Global food, waste not, want not. London, 2013. Available online at: http://www.imeche.org/Libraries/Reports/IMechE_Global_F ood_Report.sflb.ashx

[40] S. Henningsson, K. Hyde, A. Smith, and M. Campbell, "The value of resource efficiency in the food industry: a waste minimisation project in East Anglia," UK. J. Clean Prod., 12, vol. 5, pp. 505-512, 2004

[41] A.A. Kader, "Increasing food availability by reducing postharvest losses of fresh produce," Acta Hortic., 682, pp.2169-2175, 2005.

[42] M. Meeusen, and G. Hagelaar, Food losses: what do stakeholders think? A study of perception, attitude and behaviour of stakeholders to prevent food losses. Report 2008-014, Landbouw-Economisch Instituut, Den Haag, The Netherlands. 2008.

[43] FAO, Global food losses and food waste. Extent, causes and prevention. Rome. 2011.

[44] J. Gustavsson, C. Cederberg, U. Sonesson, R. van Otterdijk, and A.Meybeck, Global food losses and food waste: extent, causes and prevention. FAO, Rome. 2011.

[45] FAO/RNE, Regional Priority Framework for the Near East. FAO Regional Office for the Near East, Cairo. 2011.

[46] ADEME, Le gaspillage alimentaire au cœur de la campagne nationale grand public sur la réduction des déchets. Agence de l'Environnement et de la Maîtrise de l'Energie (ADEME), Dossier de Presse, Paris. 2010.

[47] UNEP/MAP, Mediterranean Strategy for Sustainable Development: a framework for environmental sustainability and shared prosperity. Tenth Meeting of the Mediterranean Commission on Sustainable Development (MCSD), Athens. 2005.

[48] A.Y. Hoekstra, A.K. Chapagain, M.M. Aldaya, and M.M. Mekonnen, "The Water Footprint Assessment Manual: Setting the Global Standard," Water Footprint Network; Earthscan, London \& Washington D.C., p. 224, 2011.

[49] D. Vanham, and G. Bidoglio, "A review on the indicator water footprint for the EU28," Ecol. Ind., 26, pp. 61-75, 2013. http://dx.doi.org/10.1016/j.ecolind.2012.10.021.

[50] FAO, Food balance sheets. 2012. Available at: http://faostat.fao.org/site/368/default.aspx\#ancor.

[51] S. Sáez Almendros, B. Obrador, L. Serra-Majem, and A. Bach-Faig, The sustainability of the Mediterranean dietary pattern: analysis of its environmental footprint in the 
Spanish context. Barcelona International Conference on the Mediterranean Diet. March 2012.

[52] M.M. Mekonnen, and A.Y. Hoekstra, The green, blue and grey water footprint of farm animals and animal products. Value of Water Research Report Series No. 48, UNESCOIHE, Delft, the Netherlands. 2010b.

[53] M. Zessner, K. Helmich, S. Thaler, M. Weigl, K.H. Wagner, T. Haider, M.M. Mayer, and S. Heigl, "Nutrition and land use in Austria," Österreichische Wasser - und Abfallwirtschaft, 63, pp. 95-104, 2011.

[54] World Bank Data: GDP, 2012. Available at: http://data.worldbank.org/indicator/NY.GDP.MKTP.CD

[55] L. Baroni, L. Cenci, M. Tettamanti, and M. Berati, "Evaluating the environmental impact of various dietary patterns combined with different food production systems," Eur. J. Clin. Nutr. 61, vol.2, pp. 279-86, 2007.

[56] F. Duchin, "Sustainable consumption of food: a framework for analyzing scenarios about changes in diets," Journal of Industrial Ecology, 9, vol.1-2, pp. 99-114, 2005.

[57] EC/JRC, Environmental impacts of diet changes in the EU. Technical Report, European Commission (EC), Joint Research Centre (DG JRC), Institute for Prospective Technological Studies (IPTS), Seville. 2009.

[58] C. Foster, K. Green, M. Bleda, P. Dewick, B. Evans, A. Flynn, J. Mylan, Environmental impacts of food production and consumption: a report to the Department for Environment, Food and Rural Affairs (DEFRA). Manchester Business School. DEFRA, London. 2006.

[59] T.L.T. Nguyen, J.E. Hermansen, and L. Mogensen, "Environmental consequences of different beef production systems in the EU," Journal of Cleaner Production, 18, pp. 756-766, 2010.

[60] A. Tukker, G. Huppes, J. Guinée, R. Heijungs, A. De koning, L. van Oers, S. Suh, Th. Geerken, M. Van Holderbeke, and B. Jansen, Environmental impacts of products (EIPRO).
Analysis of the life cycle environmental impacts related to the final consumption of the EU25 draft report. The Institute for Prospective Technological Studies (IPTS)/ the European Science and Technology Observatory (ESTO), April 2005, Seville, 2005.

[61] H. Steinfeld, P. Gerber, T. Wassenaar, V. Castel, M. Rosales, and C. de Haan, Livestock's long shadow: Environmental issues and options- Food and Agriculture Organization of the United Nations (FAO), Rome, 2006.

[62] P.J. Gerber, H. Steinfeld, B. Henderson, A. Mottet, C. Opio, J. Dijkman, A. Falcucci, and G. Tempio, Tackling climate change through livestock - A global assessment of emissions and mitigation opportunities. Food and Agriculture Organization of the United Nations (FAO), Rome. 2013.

[63] FAO, SAVE FOOD: Global Initiative on Food Losses and Waste Reduction. Key findings. 2013a. Available online at: http://www.fao.org/save-food/key-findings/en

[64] K.D. Hall, J. Guo, M. Dore, and C.C. Chow, The Progressive Increase of Food Waste in America and its Environmental Impact, Laboratory of Biological Modeling, National Institute of Diabetes and Digestive and Kidney Diseases, Bethesda, Maryland. 2009.

[65] BCFN, Combating Waste - Defeating the paradox of food waste. Barilla Centre for Food and Nutrition (BCFN), Parma. 2013.

[66] FAO, Towards the Future We Want: End hunger and make the transition to sustainable agricultural and food systems. Rome. 2012a. Available online at: http://www.fao.org/docrep/015/an894e/an894e00.pdf

[67] WWF Italia, Quanta natura sprechiamo? Le pressioni ambientali degli sprechi alimentari in Italia. WWF Italia Ong-Onlus, Rome. 2013.

[68] J.S.I. Ingram, From Food Production to Food Security: Developing interdisciplinary, regional-level research. PhD Thesis, Wageningen University. 2011. 